\title{
Flash Flood Hazard Mapping Using GIS and Bivariate Statistical Method at Wadi Bada'a, Gulf of Suez, Egypt
}

\author{
Sh. A. Abu El-Magd \\ Geology Department, Faculty of Science, Suez University, Suez, Egypt \\ Email: sherif_abuelmagd@yahoo.com
}

How to cite this paper: Abu El-Magd, Sh. A. (2019). Flash Flood Hazard Mapping Using GIS and Bivariate Statistical Method at Wadi Bada'a, Gulf of Suez, Egypt. Journal of Geoscience and Environment Protection, 7, 372-385.

https://doi.org/10.4236/gep.2019.78025

Received: July 8, 2019

Accepted: August 26, 2019

Published: August 29, 2019

Copyright $\odot 2019$ by author(s) and Scientific Research Publishing Inc. This work is licensed under the Creative Commons Attribution International License (CC BY 4.0).

http://creativecommons.org/licenses/by/4.0/

\begin{abstract}
The area is a part of the Egyptian Eastern Desert in the northwestward to the Gulf of Suez. It covers an area of about 542 square kilometers. Wadi Bada'a is devoid of vegetation, because of the arid climate and water scarcity. However, the present study concerns the flash flood and its impact on the industrial zone and connected road at wadi Bada'a. In this work, the bivariate statistical method using frequency ratio was used to evaluate the areas of potential risk. Geographic Information System package (GIS) was used to analyze and calculate different data sets. The different data source has been used in the research to produce a flood hazard susceptibility map of the area, including the geologic maps, Landsat- 8 imagery, land use, and soil type associated with field investigation and data collection. Spatial database with elements at risk, related features and attributes at wadi Bada'a, were constructed. Training data were created randomly in the study area to create an inventory map with testing data. The inventory location of 95 location points has been created. The inventory datasets were divided into $75 \%$ of training datasets and $25 \%$ testing data. The independent flood-related factors were evaluated by analyzing each independently and assessing their impact on flooding with inventory datasets. The flood susceptibility maps were constructed-using training and testing datasets have been used to evaluate using the success rate method. The results of the accuracy assessment showed a success rate of $76.6 \%$ of Area Under Curve. Therefore, the main road in the study area almost at high risk in many parts because of flash flood, additionally the industrial activities located in the moderate risk zone.
\end{abstract}

\section{Keywords}

Flash Flood, Frequency Ratio, Susceptibility Map, Wadi Bada’a 


\section{Introduction}

Floods are considered as one of the major natural events worldwide causing the damage to property and human loss and in numerous spots strikes all of a sudden. Hazard refers to the probability of a potentially dangerous phenomenon occurring in a given location within a specified period of time (Alexander, 1993). In spite of the fact that Egypt is situated in the dry district and precipitation seldom and regularly falling, henceforth, flooding is tricky in both developed and undeveloped territory because of the absence of arranging and database records. Adverse impacts identified with flooding have enormously expanded and there is requirement for powerful tools, demonstrating and comprehension understanding of these impacts to help mitigate the most noticeable adverse effects of flooding catastrophes and the requirement for the advancement of a framework to comprehend the risky regions. Consequences of human residence, for example, spontaneous fast urban improvement, uncontrolled developments or real changes in land use can affect the spatial and temporal pattern of the hazards. Many authors developed different methods to evaluate and produce susceptibility flood hazard maps using qualitative and quantitative techniques (Matori, 2012), artificial neural networks (ANNs) (Campolo et al., 2003; Kia et al., 2012), frequency ratio (Lee et al., 2012), decision tree (DT) (Tehrany et al., 2013), logistic regression (Pradhan, 2010a). Using geographic information systems and remote sensing images can expedite the location of areas that are likely to flood and are powerful tools to attain accurate land use maps and therefore, detection of land use changes will be possible (Youssef et al., 2005).

The water velocities have the tendency to be high in flash floods; as discharge increases, water velocity increases. With these higher velocities, streams tend to import and transport larger particles. These large particles restricted to rocks, which could be objects of infrastructures in its way. Within the study area, the industrial zone is located, counting much of heavy industry plants (cements, steel, fertilization, etc.) having thousands of individuals and equipments, in addition to infrastructures. Studying the flash floods in such area becomes essential to raise the flag of the risk before occurrences. In order to determine the flash flood risk in the study area bivariate statistical methods have been used to define the area of risk. Techniques for the reconstructing of such flooding mapping and its belongings and breaking down different impacts using remote sensing information were created before with (Mason et al., 2010; Pradhan, 2010b; Pradhan \& Lee, 2010a, 2010b; Pradhan et al., 2014; Youssef et al., 2009, 2013, 2014a, 2014b, 2014c, 2015; Youssef et al., 2016). Lee et al. (2012) mentioned that the frequency ratio is able to perform bivariate statistical analysis and the impact of classes of each conditioning factor on flooding. The weak point of this method is the relationship between the variables, which are mostly neglected with determining the suitable flood impact factors. Flood impact factors were used based on the literature review and expertise in the area. 


\section{Study Area}

The study area, including one of the major channels in the west of Suez Gulf, wadi Bada'a and located in the arid zone of Egypt. Wadi Bada'a area located between latitudes $29^{\circ} 41^{\prime} 26.34^{\prime \prime} \mathrm{N}$ and $29^{\circ} 56^{\prime} 45.43^{\prime \prime} \mathrm{N}$ and longitudes $31^{\circ} 52^{\prime} 51.09^{\prime \prime} \mathrm{E}$ and $32^{\circ} 20^{\prime} 4.41^{\prime \prime} \mathrm{E}$. The study area covered about $542 \mathrm{Km}^{2}$ (Figure 1). The Geology of the study area was dealt with many authors (Abdullah, 1993; Issawi, 2002, 2005; Osman, 2003; Issawi et al., 2009). The limestone in the study area belonging to, Mokattam Formation of Middle Eocene. Limestone contains locally flint horizons or lenses; limestone of Toura, Helwan and Suez cement plants are from this Formation. Mokattam Formation is overlain by Maadi Formation consisting of shale and limestone with local sandstone of upper Eocene. Maadi Formation, as well as overlaying Formation Gabel El Ahmar Formation (colored sand and gravel of Oligocene) and Hagul Formation (limestone, sand and gravel of Miocene are exposed in the Wadis. Abu El-Enain et al., (1995), subdivided Lithostratigraphically the exposed Eocene limestone sequence in the area between North Galala and GabalAtaqa into six formations, namely; (from oldest to youngest) the Esna Shale (only the upper part), Southern Galala, Thebes, Minia, Mokattam and Maadi. The structure of the area is controlled by the rifting of the Red Sea. Faults system is developed showing a structure of horest-graben. The fault system consists of four groups with following direction N340, N290, N250, and N195 and the wadis are controlled by normal faults. Digital elevation model (DEM) with resolution of $30 \mathrm{~m}$ of the present study shown in (Figure 2).

\section{General Methodology}

Many authors used and developed methods in GIS, multi-criteria, artificial neural networks and analytical hierarchy process, to study and evaluate susceptibility of flood risk (Campolo et al., 2003; Chau et al., 2005; Kia et al., 2012; Matori, 2012; Mukerji et al., 2009; Rozos et al., 2011). The digital elevation model (DEM) has been used as the source from which to derive topographic parameters of elevation, slope, curvature, and slope aspect in this approach. Pradhan (2009) concluded that the DEM and its derivatives play a major role in determining which areas are susceptible to flooding occurrence. A spatial database that included slope angle, DEM, curvature, geology layers, distance from the streams, land-use, and soil type datasets were used. These factors have been used in many previous studies of flooded area susceptibility mapping using GIS. Skilodimou et al. (2003) mentioned that the anthropogenic factors, including urban areas, road network, and land-use should be taken into consideration in the flood susceptibility assessment, which are related to flood events. Figure 3 shows some photography taken for flash flood impacts on the main road at wadi Bada'a and the erosion height caused by flood events. Therefore, the frequency ratio of each factor class was calculated in excel. The area ratio of flood occurrence to nonoccurrence was calculated for each factor's class. After, the frequency ratio for each factor's class was calculated from its relationship with flood events.

Randomly 95-flooded locations have been created in the study area at wadi 
Bada'a (Figure 4). Arcmap package was used to create the training and testing flooded location in the study area. A 75\% of these flooded locations were treated as a training location for the model, where the remaining $25 \%$ were used as a testing location for the model. In this study, different parameters were classified using manual classification schemes in GIS as follows.

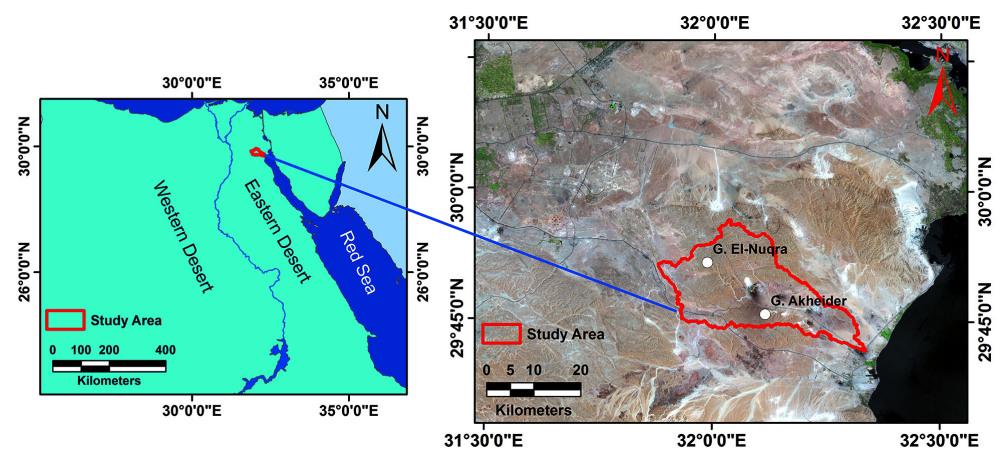

Figure 1. Location map of the study area (Red polygon).

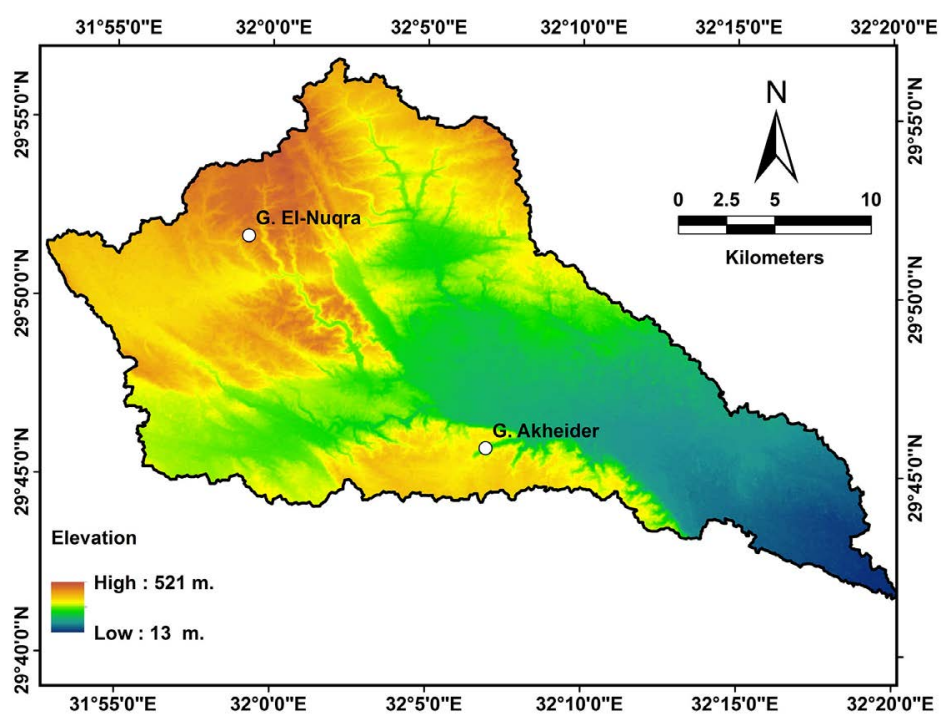

Figure 2. Digital Elevation Model showing the road path in the study area.

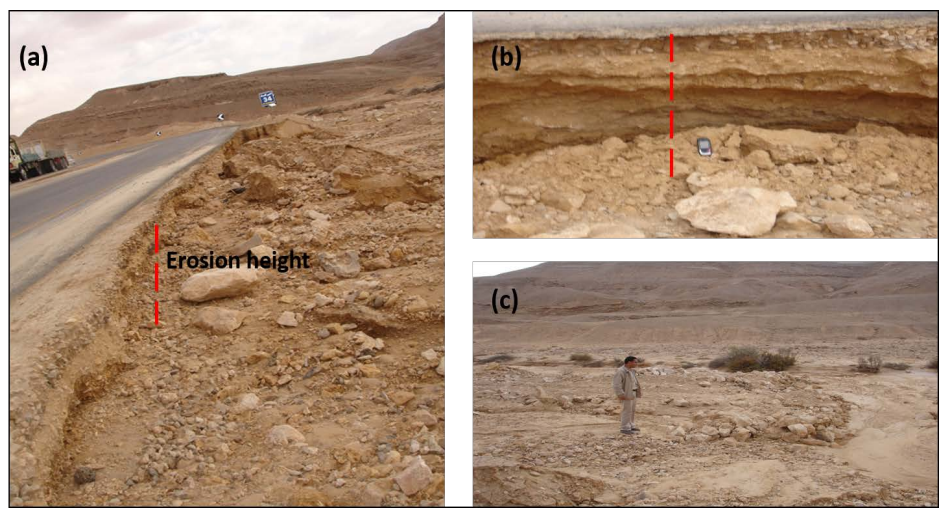

Figure 3. Shows damages caused by flood in the road, (a) \& (b) under cutting of the road and the erosion height, (c) flood carrying sediments. 


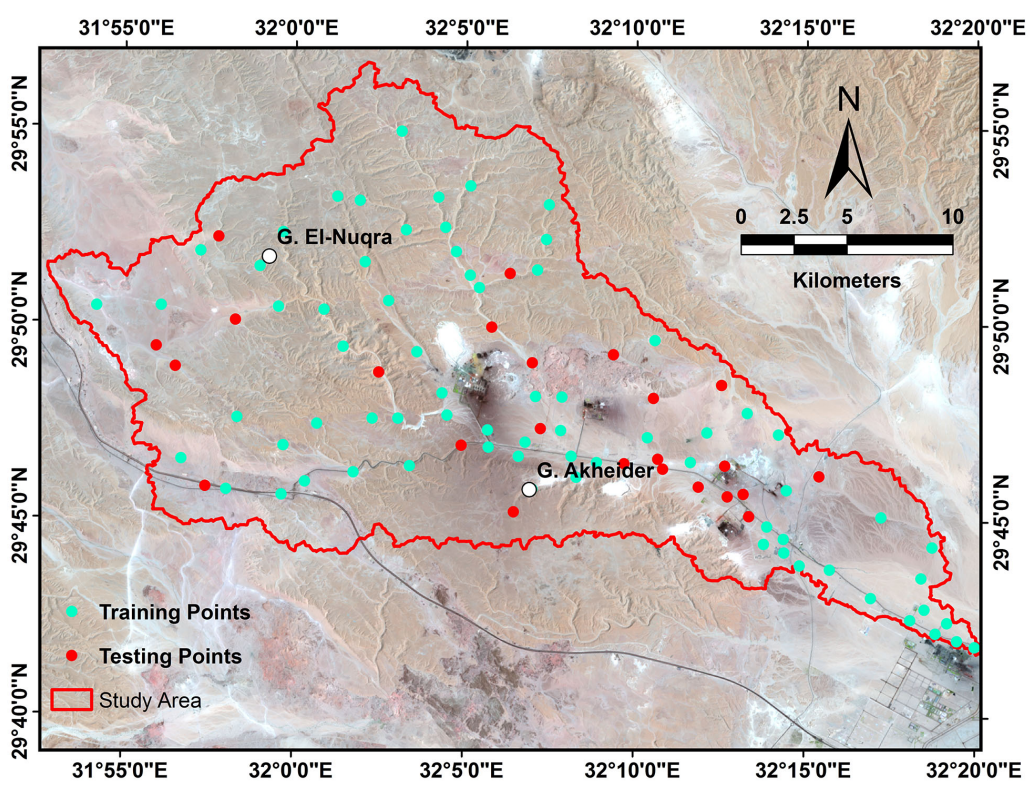

Figure 4. Flood inventory data used to validate the model.

- DEM, the elevation in the study area ranges from $13 \mathrm{~m}$ to $521 \mathrm{~m}$ above the mean sea level, and it has been classified to six classes (Figure 5(a)).

- In case of slope angle, was classified into six classes (Figure 5(b)).

- Curvature, in the study area 3 classes of curvature has been classified (Figure $5(c))$.

- Geology of the study area classified into six sedimentary units, wadi deposits, Pliocene deposits, Miocene deposits, sand and gravels of Oligocene age, Upper and Middle Eocene deposits from top to down (Figure 5(d)).

- Stream, distance from the stream classified into 6 classes $(50 \mathrm{~m}, 100 \mathrm{~m}, 200$ $\mathrm{m}, 300 \mathrm{~m}, 400 \mathrm{~m}$, and above $400 \mathrm{~m}$ ) using buffer tool in Arcmap (Figure $5(\mathrm{e}))$.

- Land-use, and soil texture has been classified into 3 classes and 2 classes respectively (Figure 5(f) and Figure 5(g)).

\subsection{Frequency Ratio}

The theoretical expression of frequency ratio (FR), as well as its usage in flood susceptibility mapping, has been reported in the studies conducted by (Yilmaz, 2009; Tehrany et al., 2013). Tehrany et al. (2014a, 2014b) indicated that the greater the ratio above unity, the stronger the relationship between flood occurrence and the given factor's class attribute, and the lower the ratio below unity, the lesser the relationship between flood occurrence and the given factor's class attribute. A simple geospatial assessment tool for understanding the probabilistic relationship between dependent and independent variables, including spatial data sets with multiple classification levels, can be applied to the FR model. Frequency ratio as bivariate statistical method describes the spatial relationship between flash floods with each variable class. Laxton (1996) mentioned that the 
frequency ratio (FR) can be defined as the ratio of the area where flash flooding hazards may occur to the total study area, or the ratio of the probability of a flash flood hazard occurrence to a non-occurrence as shown in the following Equation (Equation (1)).

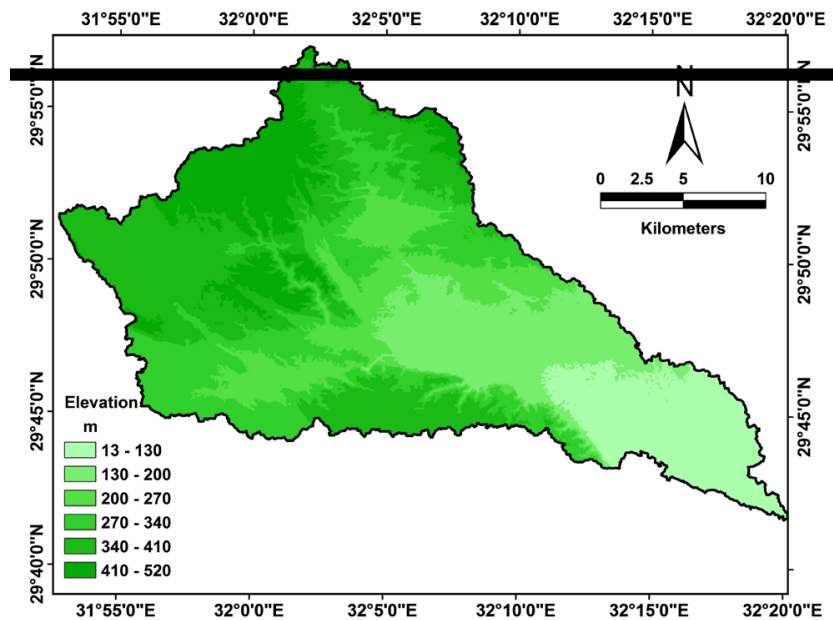

(a)

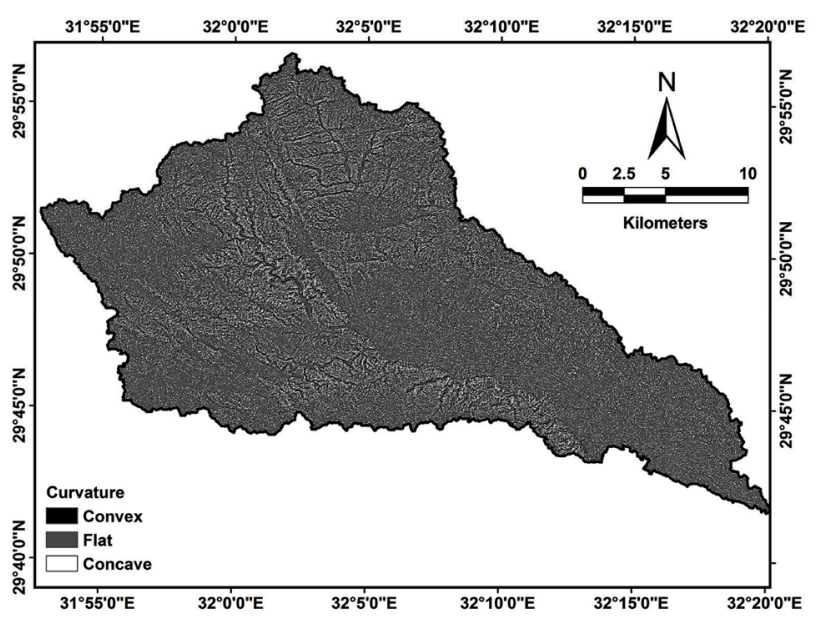

(c)

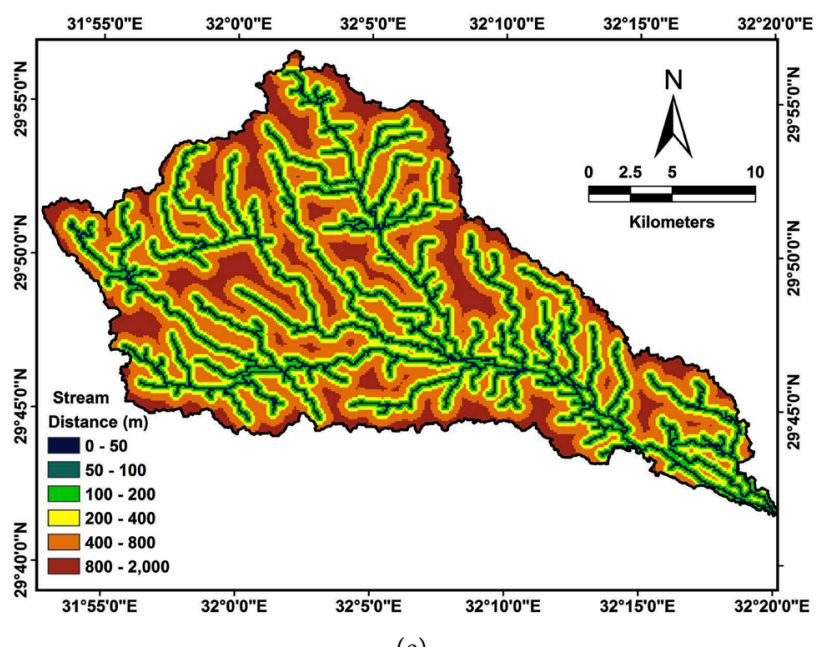

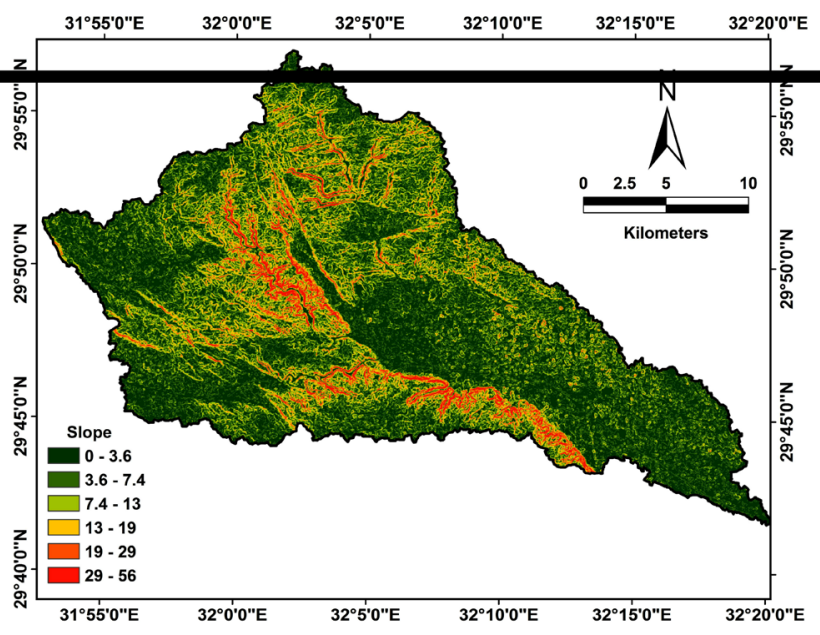

(b)

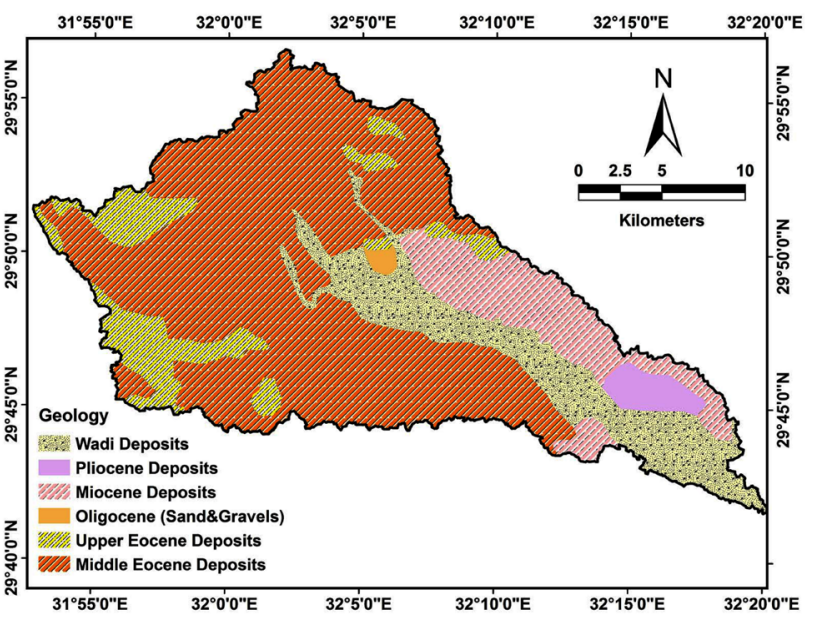

(d)

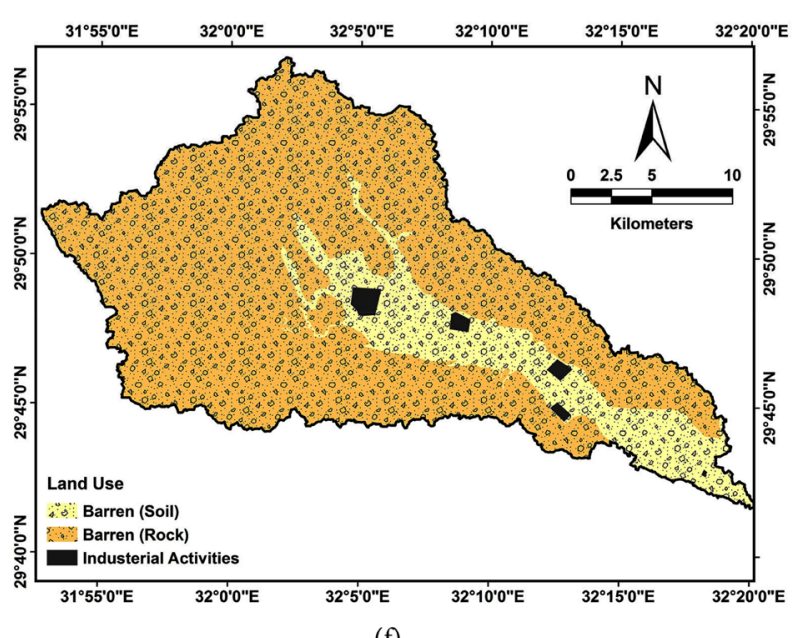




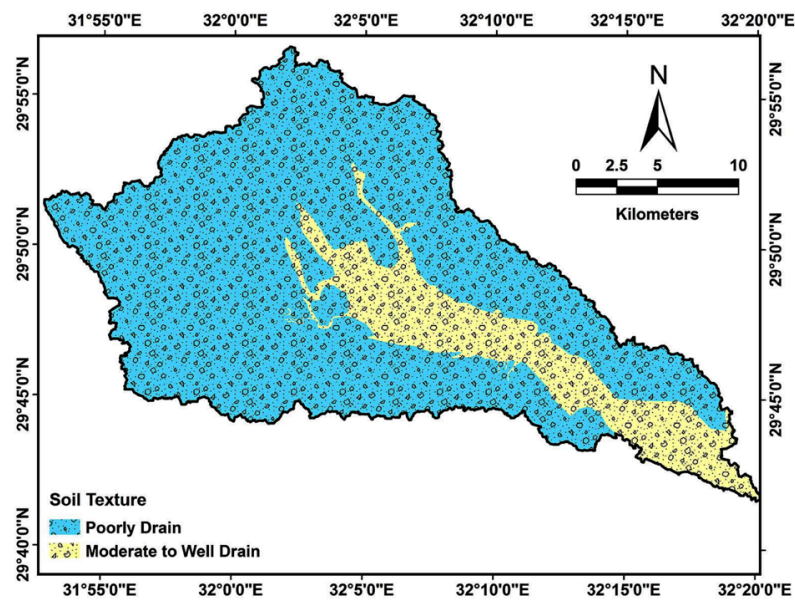

(g)

Figure 5. List of all data layers. (a) Elevation, (b) slope, (c) curvature, (d) geological units, (e) distance from streams, and (f) land-use, (g) soil texture.

$$
F R=\frac{A / B}{M / N}
$$

where $A$ is the number of pixels with a flash flooding hazard for each class of each parameter; $B$ is the total number of pixels with flash flooding hazards in study area; $M$ is the number of pixels for each class of the parameter; and $N$ is total number of pixels in the study area.

Frequency ratio $(F R)$ is the flash flooding hazard susceptibility index that was calculated in the above-mentioned equation, (Table 1) indicated the results of FR analysis of each variable. $A$ represents the number of flash flooding hazards for each parameter. $B$ represents the total number of flash flooding hazards across all 71-hazard locations that were selected as training data. $M$ represents the number of pixels for each parameter, and $N$ represents the number of pixels in the study domain. Flash flood susceptibility index (FSI) can be expressed in the following equation (Equation (2)):

$$
F S I=\sum F R
$$

where FSI is the flood susceptibility index, and FR is the frequency ratio of each variables or factors.

In order to produce a flash flooding hazard susceptibility map in the study area, the FSI was calculated by summing each weighted factor using the following equation:

$F S I=($ Slope angle $) F R+($ Elevation $) F R+($ Curvature $) F R+($ Geology $) F R+$ (Land-use) $F R+$ (Soil texture) $F R+$ (Distance from Streams) $F R$

\section{Results and Discussion}

Botzen, et al., (2013) mentioned that the lower elevation areas are more susceptible to flooding. Slope also influenced the amount of surface runoff and infiltration, consistent with earlier findings (Kazakis, et al., 2015). In the study area, 
areas of low to very low susceptibility accounted for $75 \%$ of the whole catchment area (Table 2). From the whole catchment areas the high to very high susceptibility accounted for $8 \%$ and $3 \%$. Activities, infrastructures, and future development located in these areas has to be aware of the potential hazards caused by flash flooding, as there are many major cement plants, steel industry and others

Table 1. Frequency ratio (FR) analysis for all parameter classes and factors.

\begin{tabular}{|c|c|c|c|c|c|}
\hline Factor & Factor Classes & $\%$ of Points & $\%$ of class area & FR & PR \\
\hline \multirow{6}{*}{ Slope Angle } & 1 & 63.38 & 33.78 & 1.88 & \multirow{6}{*}{0.017} \\
\hline & 2 & 22.54 & 34.63 & 0.65 & \\
\hline & 3 & 5.63 & 18.38 & 0.31 & \\
\hline & 4 & 5.63 & 8.38 & 0.67 & \\
\hline & 5 & 2.82 & 3.64 & 0.77 & \\
\hline & 6 & 0.00 & 1.20 & 0.00 & \\
\hline \multirow{6}{*}{ Elevation } & 1 & 25.35 & 12.90 & 1.97 & \multirow{6}{*}{0.010} \\
\hline & 2 & 19.72 & 14.55 & 1.35 & \\
\hline & 3 & 26.76 & 13.54 & 1.98 & \\
\hline & 4 & 16.90 & 20.33 & 0.83 & \\
\hline & 5 & 8.45 & 26.23 & 0.32 & \\
\hline & 6 & 2.82 & 12.45 & 0.23 & \\
\hline \multirow{6}{*}{ Geology } & 1 & 53.52 & 59.65 & 0.90 & \multirow{6}{*}{0.011} \\
\hline & 2 & 28.17 & 15.60 & 1.81 & \\
\hline & 3 & 7.04 & 10.25 & 0.69 & \\
\hline & 4 & 2.82 & 2.22 & 1.27 & \\
\hline & 5 & 0.00 & 0.44 & 0.00 & \\
\hline & 6 & 8.45 & 11.83 & 0.71 & \\
\hline \multirow{3}{*}{ Curvature } & 1 & 11.27 & 18.40 & 0.61 & \multirow{3}{*}{0.013} \\
\hline & 2 & 80.28 & 66.30 & 1.21 & \\
\hline & 3 & 8.45 & 15.29 & 0.55 & \\
\hline \multirow{6}{*}{$\begin{array}{l}\text { Distance from } \\
\text { Stream }\end{array}$} & 1 & 94.37 & 10.92 & 8.64 & \multirow{6}{*}{0.037} \\
\hline & 2 & 5.63 & 19.28 & 0.29 & \\
\hline & 3 & 0.00 & 23.09 & 0.00 & \\
\hline & 4 & 0.00 & 18.98 & 0.00 & \\
\hline & 5 & 0.00 & 13.03 & 0.00 & \\
\hline & 6 & 0.00 & 14.71 & 0.00 & \\
\hline \multirow{3}{*}{ Land-use } & 1 & 66.20 & 81.72 & 0.81 & \multirow{3}{*}{0.027} \\
\hline & 2 & 33.80 & 17.22 & 1.96 & \\
\hline & 3 & 0.00 & 1.06 & 0.00 & \\
\hline \multirow{2}{*}{ Soil Texture } & 1 & 66.20 & 81.72 & 0.81 & \multirow{2}{*}{0.015} \\
\hline & 2 & 33.80 & 18.28 & 1.85 & \\
\hline
\end{tabular}


Table 2. Hazard classes and corresponding area.

\begin{tabular}{ccc}
\hline Class & Area $\left(\mathrm{m}^{2}\right)$ & Percentage \\
\hline V. Low & $257,136,800$ & $48 \%$ \\
Low & $147,441,600$ & $27 \%$ \\
Moderate & $75,932,400$ & $14 \%$ \\
High & $42,141,600$ & $8 \%$ \\
V. High & $17,016,000$ & $3 \%$ \\
\hline
\end{tabular}

in these areas located in the areas of moderate susceptible flash flood hazard (Figure 6). However, it is clear from the results that the very low and low susceptibility classes are mainly located at high elevation and high slope angle areas. In case of slope angle, the frequency ratio found that the most flash flood hazards appear at low slope angle. The slope angle class of 0 - 3.68 degree has the highest frequency ratio value 1.88 , while the highest slope angle class has a lowest frequency ratio value of zero. The frequency ratio model showed that most flash flooding hazards are located at elevations less than $130 \mathrm{~m}$ in elevation, which had the highest frequency ratio value. Higher Elevations than $400 \mathrm{~m}$ in the study area had the lowest frequency ratio value of zero with low flash flood hazard. For the curvature parameter, the concave area indicating low susceptibility to flash flooding with lowest frequency ratio value of 0.55 . On the hand, flat areas proved to be the most prone to flooding with the highest frequency ratio value of 1.21 and the convex had the low FR values of 0.61 . For the geology factor, the Quaternary and wadi deposits class had the highest frequency ratio value of 1.81; providing the high susceptibility rock unit in the study area, followed by Pliocene deposits. Oligocene rock units provide the lowest frequency ratio value of zero indicating low susceptibility. As for the distance from the stream, as the distance from the streams increases the frequency ration decreases; results showed the class of less than $50 \mathrm{~m}$ distance had the highest frequency ratio value of 8.64 with the highest flash flooding susceptibility and a class of 100 $\mathrm{m}$ distance had a value of 0.29 . Distance from streams classes of more than 200 $\mathrm{m}$ distance had the lowest frequency ratio values. For the land-use parameter, the frequency ratio value for barren soil type was 1.96 and the rocky type, frequency ratio value was 0.81 . For soil texture, the results found that wadi deposits with moderately drain had the highest frequency ratio value of 1.85 . The resulted susceptibility map (Figure 7) indicated that the road located in the high hazard zone where the industrial activities located in the moderate hazard zone, giving a warning to live hood and activities for flash flood.

\section{Validating the Model}

The AUC values range from 0.5 to 1.0. The value of 1.0 represented the highest accuracy, showing that the model was completely capable of predicting disaster occurrence without any bias (Pradhan et al., 2010). The most important step is to validate the calculated model which reflects the accuracy of the model results, 
however many of statistical methods can be used; in the current research success rate has been used to validate the model (Figure 8). A total of 95-flood hazard's location were generated and located on the map. The success rate illustrates how well the estimators perform. In the study area, the calculated index values of all the cells were stored in descending order, for having relative ranks of predicted pattern. Moreover, after the descending ordered of all the cell's value, then we went for classification into 100 classes with $1 \%$ intervals. To quantitatively compare the results, the areas under the curve were recalculated for when the total area is represented by 1 , which means perfect prediction accuracy. Thus, qualitatively the area under a curve (AUC) can be used to evaluate the prediction accuracy. The area under the curve has been calculated using excel the result in the area indicates that the area ratio was 0.766 and accordingly the prediction accuracy is $76.6 \%$ for the modeled watershed. Comparisons of the field investigation of the flood impact on the road with the susceptibility map show good matching between both. Meanwhile, an area under curve (AUC) method evaluated and the results of model accuracy show values from $74 \%$ to $86 \%$ (Cao et al., 2016).

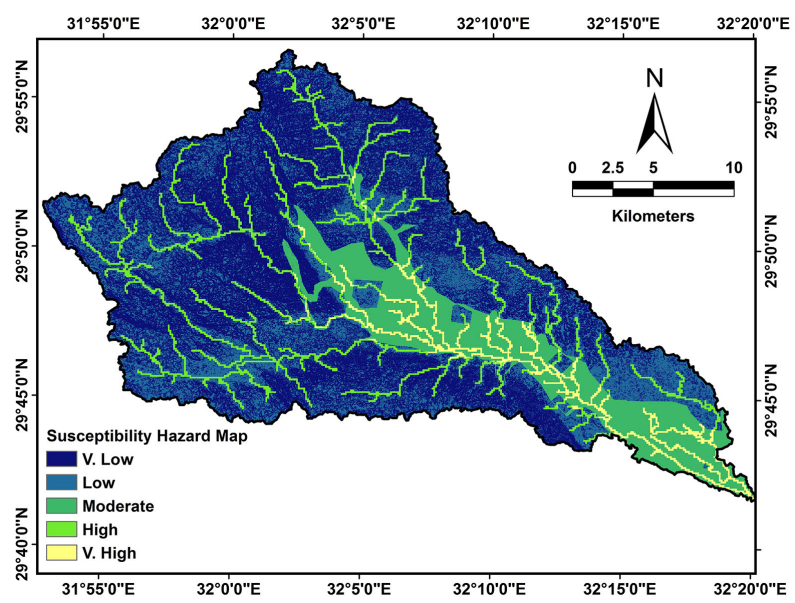

Figure 6. Susceptibility hazard map of the study area.

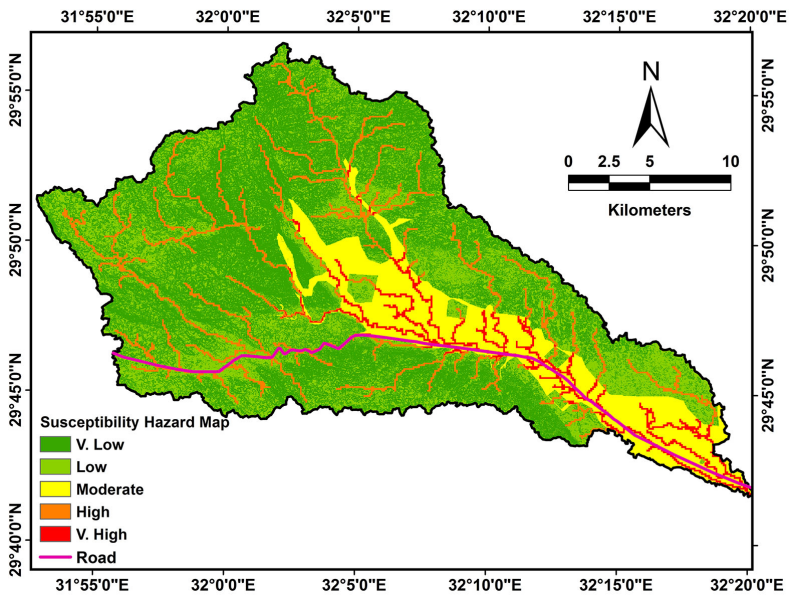

Figure 7. Susceptibility hazard map showing the hazard on the main road of the study area. 


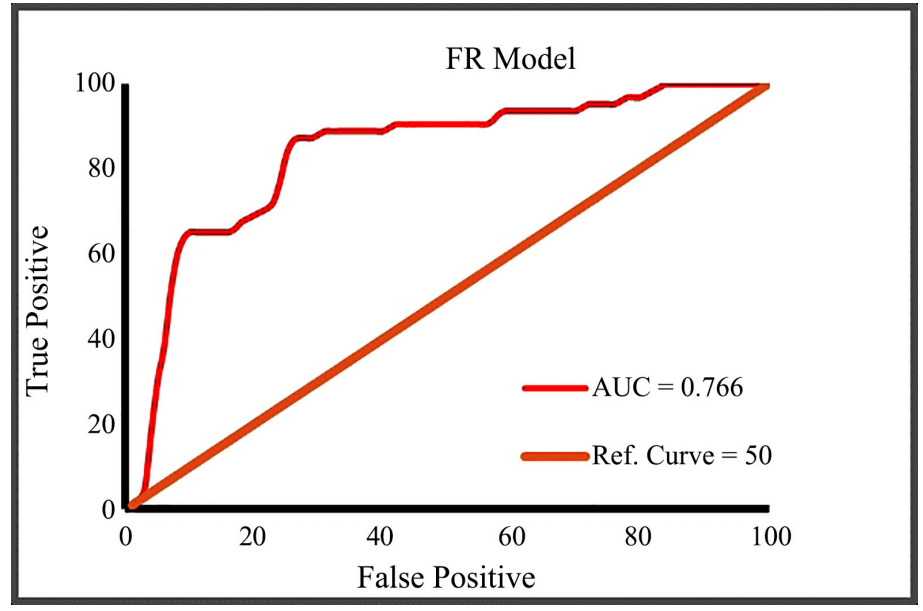

Figure 8. Prediction rate carve in the study area.

\section{Conclusion}

Frequency ratio (FR) model with a GIS-based model was applied to generate flash flood hazard susceptibility map (FSI) for the study area of wadi Bada'a, west of Suez Gulf. In order to construct the model 95 flash flood locations were used and prepared in Arcmap for models, where $75 \%$ of these datasets (71-flooded location) were used randomly as training locations for building the model. The remaining 25\% (24 validating data) as testing locations were used for model testing and validation. In the current study, based on the literatures review and field investigation, seven of parameters have been selected to generate the flash flood susceptibility index map (FSI). These parameters included slope angle, elevation, curvature, geology, distance from the streams, land-use, and soil texture. The input parameters were classified using the natural breaks method and manual classification method. The generated model produced susceptibility map of five classes, very low hazard, low hazard, moderate hazard, high hazard, and very high hazard. However, the areas of low elevation and low slope angles area indicates high frequency ratio values. The contribution of susceptibility hazard map indicates that the flood more likely occurred nearby the main road, which means that the low land and low slope areas are favorites for the flood occurrence. It is clear from the susceptibility map that the main road in wadi Bada'a located in high to very high susceptible zone. The area of high and very high risk covers about $11 \%$ of basin area, while the low to moderate flood risk covers about $43 \%$. Based on the validating model and the resulted value, which was $76.6 \%$ the flash flooding susceptibility map generated by the frequency ratio approach was reliable and applicable. AUC results of frequency ratio model performed well in training and prediction with $76.6 \%$. The resulted susceptibility map indicated that the road located in the high hazard zone where the industrial activities located in the moderate hazard zone. Since the road and industrial activities located in high and moderate risk zone, awareness system has to be activated in the area for flood mitigation. 


\section{Acknowledgements}

The author is thankful to anonymous reviewer for their valuable suggestions to improve the manuscript in the present form.

\section{Conflicts of Interest}

The author declares no conflicts of interest regarding the publication of this paper.

\section{References}

Abdallah, M. A. (1993). Structural Geology of the Area between El Galala El-Bahariya and Gabal Okheider, Egypt (p. 199). PhD Thesis, Cairo: Faculty of Science-Ain Shams University.

Abu El-Enain, F. M., Ali, M. M., \& Ismail, A. S. (1995). Petrography, Geochemistry and Depositional History of the Eocene Rocks in the Area between Northern Galala and Gabal Ataqa, Western Gulf of Suez, Egypt. Annals of the Geological Survey of Egypt, 20, 551-576.

Alexander, D. (1993). Natural Disasters. London: UCL Press.

Botzen, W. J., Aerts, J. C., \& van den Bergh, J. C. (2013). Individual Preferences for Reducing Flood Risk to Near Zero through Elevation. Mitigation and Adaptation Strategies for Global Change, 18, 229-244. https://doi.org/10.1007/s11027-012-9359-5

Campolo, M., Soldati, A., \& Andreussi, P. (2003). Artificial Neural Network Approach to Flood Forecasting in the River Arno. Hydrological Sciences Journal, 48, 381-398. https://doi.org/10.1623/hysj.48.3.381.45286

Cao, C., Xu, P. H., Wang, Y. H., Chen, J. P., Zheng, L. J., \& Niu, C. C. (2016). Flash Flood Hazard Susceptibility Mapping Using Frequency Ratio and Statistical Index Methods in Coalmine Subsidence Areas. Sustainability, 8, 948. https://doi.org/10.3390/su8090948

Chau, K., Wu, C., \& Li, Y. (2005). Comparison of Several Flood Forecasting Models in Yangtze River. Journal of Hydrologic Engineering, 10, 485-491. https://doi.org/10.1061/(ASCE)1084-0699(2005)10:6(485)

Issawi, B. (2002). Egypt during the Phanerozoic. In 6th International Conference on the Geology of the Arab World (Vol. 2, pp. 401-450). Egypt: Cairo University.

Issawi, B. (2005). Archean-Phanerozoic Birth and Development of the Egyptian Land. In 1st International Conference on the Geology of the Tethys (Vol. 2, pp. 380-380). Egypt: Cairo University.

Issawi, B., Francis, M., Youssef, A., \& Osman, R. (2009). The Phanerozoic of Egypt: A Geodynamic Approach (p. 589). Geol. Surv. Egypt, Spec. Publ., No. 81, Cairo: Egyptian Geological Survey.

Kazakis, K., Kougias, I., \& Patsialis, T. (2015). Assessment of Flood Hazard Areas at a Regional Scale Using an Index Based Approach and Analytical Hierarchy Process: Application in Rhodope-Evros Region, Greece. Science of the Total Environment, Science of the Total Environment, 538, 555-563. https://doi.org/10.1016/j.scitotenv.2015.08.055

Kia, M. B., Pirasteh, S., Pradhan, B., Mahmud, A. R., Sulaiman, W. N. A., \& Moradi, A. (2012). An Artificial Neural Network Model for Flood Simulation Using GIS: Johor River Basin, Malaysia. Environmental Earth Sciences, 67, 251-264. https://doi.org/10.1007/s12665-011-1504-Z

Laxton, J. L. (1996). Geographic Information Systems for Geoscientists-Modelling with GIS-Bonhamcarter, GF. International Journal of Geographical Information Science, 
10, 355-356. https://doi.org/10.1080/02693799608902084

Lee, M. J., Kang, J. E., \& Jeon, S. (2012). Application of Frequency Ratio Model and Validation for Predictive Flooded Area Susceptibility Mapping Using GIS. In 2012 IEEE International Geoscience and Remote Sensing Symposium (IGARSS) (pp. 895-898), Munich. https://doi.org/10.1109/igarss.2012.6351414

Mason, D. C., Speck, R., Devereux, B., Schumann, G. P., Neal, J. C., \& Bates, P. D. (2010). Flood Detection in Urban Areas Using TerraSAR-X. IEEE Transactions on Geoscience and Remote Sensing, 48, 882-894. https://doi.org/10.1109/tgrs.2009.2029236

Matori, A. (2012). Detecting Flood Susceptible Areas Using GIS-Based Analytic Hierarchy Process. In International Conference on Future Environment and Energy, Singapore.

Mukerji, A., Chatterjee, C., \& Raghuwanshi, N. S. (2009). Flood Forecasting Using ANN, Neuro-Fuzzy, and Neuro-GA Models. Journal of Hydrologic Engineering, 14, 647-652. https://doi.org/10.1061/(ASCE)HE.1943-5584.0000040

Osman, R. (2003). New Findings in the Eocene Stratigraphy of Gebel Ataqa-Northern Galala, North Eastern Desert, Egypt. Journal Sedimentology of Egypt, 11, 95-109.

Pradhan, B. (2009). Groundwater Potential Zonation for Basaltic Watersheds Using Satellite Remote Sensing Data and GIS Techniques. Central European Journal of Geosciences, 1, 120-129. https://doi.org/10.2478/v10085-009-0008-5

Pradhan, B. (2010a). Flood Susceptible Mapping and Risk Area Delineation Using Logistic Regression, GIS and Remote Sensing. Journal of Spatial Hydrology, 9, 1-18.

Pradhan, B. (2010b). Landslide Susceptibility Mapping of a Catchment Area Using Frequency Ratio, Fuzzy Logic and Multivariate Logistic Regression Approaches. Journal of the Indian Society of Remote Sensing, 38, 301-320.

https://doi.org/10.1007/s12524-010-0020-z

Pradhan, B., \& Lee, S. (2010a). Delineation of Landslide Hazard Areas on Penang Island, Malaysia, by Using Frequency Ratio, Logistic Regression, and Artificial Neural Network Models. Environmental Earth Sciences, 60, 1037-1054.

https://doi.org/10.1007/s12665-009-0245-8

Pradhan, B., \& Lee, S. (2010b). Landslide Susceptibility Assessment and Factor Effect Analysis: Back-Propagation Artificial Neural Networks and Their Comparison with Frequency Ratio and Bivariate Logistic Regression Modelling. Environmental Modelling \& Software, 25, 747-759. https://doi.org/10.1016/j.envsoft.2009.10.016

Pradhan, B., Hagemann, U., Tehrany, M. S., \& Prechtel, N. (2014). An Easy to Use ArcMap Based Texture Analysis Program for Extraction of Flooded Areas from TerraSAR-X Satellite Image. Computers \& Geosciences, 63, 34-43.

https://doi.org/10.1016/j.cageo.2013.10.011

Pradhan, B., Oh, H. J., \& Buchroithner, M. (2010). Weights-of-Evidence Model Applied to Landslide Susceptibility Mapping in a Tropical Hilly Area. Geomatics Natural Hazards \& Risk, 1, 199-223. https://doi.org/10.1080/19475705.2010.498151

Rozos, D., Bathrellos, G. D., \& Skillodimou, H. D. (2011). Comparison of the Implementation of Rock Engineering System and Analytic Hierarchy Process Methods, upon Landslide Susceptibility Mapping, Using GIS: A Case Study from the Eastern Achaia County of Peloponnesus, Greece. Environmental Earth Sciences, 63, 49-63. https://doi.org/10.1007/s12665-010-0687-z

Skilodimou, H., Livaditis, G., Bathrellos, G., \& Verikiou-Papaspiridakou, E. (2003). Investigating the Flooding Events of the Urban Regions of Glyfada and Voula, Attica, Greece: A Contribution to Urban Geomorphology. Geografiska Annaler Series A, 85, 197-204. https://doi.org/10.1111/1468-0459.00198 
Tehrany, M. S., Pradhan, B., \& Jebur, M. N. (2013). Spatial Prediction of Flood Susceptible Areas Using Rule Based Decision Tree (DT) and a Novel Ensemble Bivariate and Multivariate Statistical Models in GIS. Journal of Hydrology, 504, 69-79. https://doi.org/10.1016/j.jhydrol.2013.09.034

Tehrany, M. S., Pradhan, B., \& Jebur, M. N. (2014a). Flood Susceptibility Mapping Using a Novel Ensemble Weights-of-Evidence and Support Vector Machine Models in GIS. Journal of Hydrology, 512, 332-343. https://doi.org/10.1016/j.jhydrol.2014.03.008

Tehrany, M. S., Lee, M. J., Pradhan, B., Jebur, M. N., \& Lee, S. (2014b). Flood Susceptibility Mapping Using Integrated Bivariate and Multivariate Statistical Models. Environmental Earth Sciences, 72, 1-15. https://doi.org/10.1007/s12665-014-3289-3

Yilmaz, I. (2009). Landslide Susceptibility Mapping Using Frequency Ratio, Logistic Regression, Artificial Neural Networks and Their Comparison: A Case Study from Kat Landslides (Tokat-Turkey). Computers \& Geosciences, 35, 1125-1138.

https://doi.org/10.1016/j.cageo.2008.08.007

Youssef, A. M., Al-kathery, M., \& Pradhan, B. (2014a). Landslide Susceptibility Mapping at Al-Hasher Area Jizan (Saudi Arabia) Using GIS-Based Frequency Ratio and Index of Entropy Models. Geosciences Journal, 19, 113-134.

https://doi.org/10.1007/s12303-014-0032-8

Youssef, A. M., Pradhan, B., Jebur, M. N., \& El-Harbi, H. M. (2014b). Landslide Susceptibility Mapping Using Ensemble Bivariate and Multivariate Statistical Models in Fayfa Area Saudi Arabia. Environmental Earth Sciences, 73, 3745-3761. https://doi.org/10.1007/s12665-014-3661-3

Youssef, A. M., Al-kathery, M., Pradhan, B., \& Elsahly, T. (2014c). Debris Flow Impact Assessment along the Al-Raith Road, Kingdom of Saudi Arabia, Using Remote Sensing Data and Field Investigations. Geomatics, Natural Hazards and Risk, 7, 620-638. https://doi.org/10.1080/19475705.2014.933130

Youssef, A. M., Maerz, N. H., \& Hassan, A. M. (2009). Remote Sensing Applications to Geological Problems in Egypt: Case Study, Slope Instability Investigation, Sharm El-Sheikh/Ras-Nasrani Area, Southern Sinai. Landslides, 6, 353-360.

https://doi.org/10.1007/s10346-009-0158-3

Youssef, A. M., Pradhan, B., \& Maerz, N. H. (2013). Debris Flow Impact Assessment Caused by 14 April 2012 Rainfall along the Al-Hada Highway, Kingdom of Saudi Arabia Using High-Resolution Satellite Imagery. Arabian Journal of Geosciences, 7, 2591-2601. https://doi.org/10.1007/s12517-013-0935-0

Youssef, A. M., Pradhan, B., \& Sefry, S. A. (2016). Flash Flood Susceptibility Assessment in Jeddah City (Kingdom of Saudi Arabia) Using Bivariate and Multivariate Statistical Models. Environmental Earth Sciences, 75, 12.

https://doi.org/10.1007/s12665-015-4830-8

Youssef, A. M., Sefry, S. A., Pradhan, B., \& Abu Alfadail, E. (2015). Analysis on Causes of Flash Flood in Jeddah City (Kingdom of Saudi Arabia) of 2009 and 2011 Using Multi-Sensor Remote Sensing Data and GIS. Geomatics, Natural Hazards and Risk, 7, 1018-1042. https://doi.org/10.1080/19475705.2015.1012750

Youssef, M., Abdel Moneim, A. A., \& Abu El-Magd, S. A. (2005). Flood Hazard Assessment and Its Associated Problems Using Geographic Information Systems, Sohag Governorate, Egypt. In The Fourth International Conference on the Geology of Africa (Vol. 1, pp. 1-17). 